International Research Journal of Management, IT \& Social Sciences
Available online at https://sloap.org/journals/index.php/irjmis/
Vol. 7 No. 3, May 2020, pages: 98-103
ISSN: 2395-7492
https://doi.org/10.21744/irjmis.v7n3.921

\title{
Development of culture village through service quality analysis to customer satisfaction
}

$\begin{array}{r}\begin{array}{r}\text { Ade Ruly Sumartini }{ }^{\text {a }} \\ \text { Ida Ayu Agung Idawati }\end{array} \\ \hline\end{array}$

Article history:

Submitted: 18 March 2020

Revised: 27 April 2020

Accepted: 09May 2020

\section{Keywords:}

cultural village development; customer satisfaction;

Kertalangu cultural village;

physical evidence;

service quality;

\begin{abstract}
Cities tend to be the focus of development, including the development of the tourism sector. This tendency is motivated by the social demographic factors of the population of the city is much easier to accept the latest issues related to modernization and economic empowerment. Denpasar, as the center of the city, still has green and beautiful land, which is Kertalangu Cultural Village. As a tourist destination, there are many facilities and infrastructures in Kertalangu Cultural Village needs to be improved. The purpose of this research is to find out and provide empirical evidence about the Development of Kertalangu Cultural Village Based on Analysis of Service Quality on Customer Satisfaction. The data collection method uses a questionnaire distributed to 100 respondents. Data analysis techniques used multiple regression analysis using mixed methods, both qualitatively and quantitatively. The results showed that service quality variables such as responsiveness, assurance, empathy, and reliability had a positive and significant effect on customer satisfaction. The service quality variable in the form of tangible (physical evidence) has a positive effect but not significant. The results of this study explain to be a reference for managers to evaluate the existing physical facilities so that visitors can be more satisfied with the existence of physical facilities that are maintained and also the development of facilities in the Kertalangu Cultural Village in the form of adding cultural-based facilities.
\end{abstract}

International research journal of management, IT and social sciences (C) 2020. This is an open access article under the CC BY-NC-ND license (https://creativecommons.org/licenses/by-nc-nd/4.0/).

Corresponding author:

Ade Ruly Sumartini,

Warmadewa University, Denpasar, Indonesia.

Email address: aderuly81@gmail.com

Warmadewa University, Denpasar, Indonesia

Warmadewa University, Denpasar, Indonesia 


\section{Introduction}

Tourism in Indonesia is held to increase economic growth, improving people's welfare, eradicating poverty, overcoming unemployment, preserving nature, the environment, and resources, advancing culture, promoting the nation's image, fostering a sense of the image of the motherland, strengthening national identity and unity as well as strengthening national friendship (UU RI No.10 2009). Indonesian tourism, especially in Bali, has had a significant impact on the regional economy, confirmed by the study of a consultant team from Bali. The project management and Comprehensive Tourism Development Plan for Bali (Erawan, 1993; Parasuraman, 2011), concluded that tourism had become a generator for the development of Bali, at least in the last two decades. It was further said that the tourism sector would remain a leading sector in the economic development of the Bali region in the future, including the possibility of developing cultural villages in urban areas.

Denpasar as the center of the city still has green and beautiful land, namely Kertalangu Cultural Village as a tourist destination, located on 70 hectares of land, this place deserves to be appreciated because it has maintained the face of the capital city to be greener and become one of the sources of significant oxygen donors for unraveling the increasing pollution. The city community and tourists make it a place to relax, rest, and recreation with family, eliminating fatigue and boredom from daily routine. Beautiful rice fields surround Kertalangu Cultural Village and lush gardens there is also the World Peace Monument with the symbol of a large gong equipped with statues from world-famous figures, who support peace from 9 countries. More dominated by views of rice fields, complete with jogging tracks, game rides, fishing ponds, and various culinary delights.

Pre research made in the Kertalangu Cultural Village is still an obstacle. Many attractions and tourist facilities aimed at visitors are currently in poor condition, such as jogging tracks that have been perforated in several places, poorly maintained venue conditions, plastic debris littering around trenches and fishing ponds, poorly maintained signboards, damaged shuttle bus notice boards and also poorly organized park conditions. The obstacle of Kertalangu Cultural Village product requires further handling, where tourism products should be perceived well by tourists because it is related to the impression that is obtained while in the tourist destination. Following the opinion of Suwantoro (1997), which states that the image of tourism in an area essentially depends on the availability of tourist products. For this reason, it is deemed necessary to conduct a study of tourist satisfaction to the Kertalangu Cultural Village as one of the tourist attraction businesses in Denpasar. Many benefits are received by the company with the achievement of a high level of customer satisfaction. A high level of customer satisfaction will increase customer loyalty and prevent customer turnover, reduce customer sensitivity to prices, reduce the cost of marketing failures, reduce operating costs caused by increasing customer numbers, increase advertising effectiveness, and enhance business reputation (Fornell, 1992, in Aryani \& Rosinta, 2010). Consumer expectations believe in having a large role in determining product quality (goods and services) and customer satisfaction (Burger \& Cann, 1995; Perkins, 1993). In evaluating a product, consumers will use their expectations as a standard or reference. Thus, it is consumers' expectations as a reason behind why two companies in the same business can be judged differently by consumers. The results of the assessment of the level of customer satisfaction will be able to show the trend, how to make customers feel satisfied or dissatisfied (Matzler et al., 2004; Malarvizhi \& Devi, 2018). Based on the results of the customer assessment of the services of the tourism developer, the company can make corrections to the performance of its services. In this case also supported by several previous studies on the analysis of service quality on customer satisfaction such as in Rianto (2017); Ligiya (2016); Massie (2016); Clara (2017); and Tangkere \& Lorraine (2017), found that the quality of service from several objects tourism in Indonesia has a significant positive effect on customer satisfaction.

Based on the background description, the formulation of the problem in this study is arranged as follows:

1) Does the quality of service received in the form of Responsiveness, Assurance, Tangible Empathy, and Reliability affect customer satisfaction in Kertalangu Culture Village?

2) How is the development of Kertalangu Cultural Village based on Analysis of Service Quality on Customer Satisfaction?

\section{Materials and Methods}

The study was conducted at the Kertalangu Cultural Village Denpasar. Determination of the sample using the purposive sampling method, with several criteria domiciled in the Bali and Visitors of Kertalangu Cultural Village, who have visited at least two times in the past six months. Data collection was carried out through a survey using a questionnaire.

Sumartini, A. R., \& Idawati, I. A. A. (2020). Development of culture village through service quality analysis to customer satisfaction. International Research Journal of Management, IT and Social Sciences, 7(3), 98-103. 
The research questionnaire included several questions regarding variables of service quality and customer satisfaction. The scale of measurement of variables uses a Likert five scale - the analysis technique using multiple linear regression analysis assisted by the SPSS program. Testing the validity and reliability of research instruments is very important to obtain valid and reliable research results. The provision of an instrument is said to be valid if it has a Pearson Product Moment correlation coefficient (r) $>0.3$ with an alpha of 0.05 (Sugiyono, 2014). An instrument is said to be reliable if it has an alpha coefficient $(\alpha)$ greater than 0.60 (Sugiyono, 2014). Before the regression model is carried out to test the hypothesis, of course, the model is free from the classic assumption test. The normality of data distribution is normal or not. Multicollinearity to found a correlation between independent variables. The heteroscedasticity to occurs variance inequality from residuals of one observation to another. Multiple linear regression analysis is used to determine whether there is an effect of service quality on customer satisfaction. Multiple linear regression expressed in the form of multiple linear regression equations (Sugiyono, 2014).

\section{Results and Discussions}

The results of the validity test showed the Pearson Correlation value is above 0.3, and the Sig 2-Tailed Value is below 0.05 , which can be concluded that $X_{1}$ (responsiveness), $X_{2}$ (assurance), $X_{3}$ (tangible), $X_{4}$ (empathy) and $X_{5}$ (reliability) are valid. The reliability test results showed that the Cronbach alpha value is 0.934 indicates the value is more than 0.6 so that it can be concluded that the research variables in this study are reliable. Normality test results show that the results of Shapiro-Wilk data processing, the significant value (probability value) obtained from 0.185 is greater than $0.05(0.185>0.05)$, it can be said that the variables in this study are normally distributed. The test results show that the Tolerance value of each independent variable (Responsiveness 0.453, Assurance 0.548, Tangible 0.571, Empathy 0.421 , and Reliability 0.403 where the value is above 0.01 . While the results of VIF indicate that for each independent variable (Responsiveness 2.207, Assurance 1.825, Tangible 1.751, Empathy 2.375, and Reliability 2.484, which have values below 10, from these results, it can be concluded that there are no symptoms of multicollinearity between independent variables in the regression model. The test of Heteroscedasticity shows that the significance of each independent variable (Responsiveness 0.992, Assurance 0.419, Tangible 0.557, Empathy 0.074, and Reliability 0.333 where the value is above 0.05 , it can be concluded that there are no symptoms of heteroscedasticity at regression model. The results of regression analysis shown, the coefficient for Responsiveness variable is 0.191 , Assurance is 0.432 , Tangible is 0.019 , Empathy is 0.254 and Reliability is 0.308 with a constant of -1.801 so the regression equation model obtained is as follows:

$$
Y=-1,801+0,191 X_{1}+0,432 X_{2}+0,019 X_{3}+0,254 X_{4}+0,308 X_{5}
$$

The regression equation shows the direction of the influence of each independent variable (Responsiveness, Assurance, Tangibles, Empathy, and Reliability) on customer satisfaction. It is shown that the variable Responsiveness, Assurance, Tangibles, Empathy, Reliability has a positive effect on customer satisfaction. These results still need to be reviewed with the results of further statistical tests, which is the coefficient of determination and the test of the partial effect of each independent variable on the dependent variable. The results of the regression calculation shown that the adjusted $\mathrm{R}$ square value is 0.752 . This means that 75.2 percent of variations in customer satisfaction variables can be explained by the variables Responsiveness $\left(\mathrm{X}_{1}\right)$, Assurance $\left(\mathrm{X}_{2}\right)$, Tangible $\left(\mathrm{X}_{3}\right)$, Empathy $\left(\mathrm{X}_{4}\right)$, and Reliability $\left(\mathrm{X}_{5}\right)$. In comparison, the remaining 24.8 percent is explained by other variables that not included in this research model.

The results of the test for the effect of responsiveness to customer satisfaction in Kertalangu Culture Village showed of 2.050 and a p-value (sig) of 0.000 below alpha $0.05(0.043<0.05)$, which means that the Responsiveness has a positive and significant effect on customer satisfaction in Kertalangu Cultural Village. The beta value in the unstandardized coefficient of the Responsiveness variable shows of 0.191 , which means that if the responsiveness variable is increased by one point, the customer satisfaction of Cultural Village will increase by $19.1 \%$. The results of this study are supported by previous research wherein his research examining the Effect of Service Quality on Customer Satisfaction in Traveling to Kampung Gajah stating that service quality has a positive and significant effect on customer satisfaction in traveling in Kampung Gajah (Ligiya, 2016; Yong et al., 2003; De Ruyter et al., 1997; Oh, 1999). The results of the test for the effect of Assurance on customer satisfaction in Cultural Village showed a value of 5.600 and a p-value (sig) of 0.000 below alpha $0.05(0.000<0.05)$ which means that Assurance has a positive and significant effect on customer satisfaction in Cultural Village. The beta value in the unstandardized coefficient of the Assurance variable shows a figure of 0.432 , which means that if the Assurance variable is increased by one point, 
customer satisfaction in the Kertalangu Cultural Village will increase by $43.2 \%$. The results of this study are supported by previous studies wherein the research examining Analysis of Service Quality and Satisfaction of Tourism Visitors in Cibuntu Tourism Village, Kuningan Regency using cartesian diagram analysis, states that Assurance has fulfilled expectations and provided satisfaction for visitors of Cibuntu Village (Rianto, 2017). The results of the test for the effect of Tangible on customer satisfaction in Culture Village showed a value of 0.293 and a p-value (sig) of 0.770 which was above alpha $0.05(0.770>0.05)$ which means that Tangible have a positive effect and but not significant on customer satisfaction in Cultural Village. The beta value in the unstandardized coefficient of the Tangible variable shows a figure of 0.019 , which means that if the Tangible variable is increased by one point, the customer satisfaction of Cultural Village will only increase by $1.9 \%$. The test results of the test for the effect of empathy on customer satisfaction in Cultural Village, show the value of t count 2.958 and p-value (sig) of 0.004 which below alpha 0.05 $(0.004<0.05)$ which means that the service is in the form Empathy has a positive and significant effect on customer satisfaction in Kertalangu Cultural Village. The beta value in the unstandardized coefficient Empathy shows of 0.254, which means that if the Empathy variable is increased by one point, customer satisfaction in Kertalangu Cultural Village will increase by $25.4 \%$. The results of this study are supported by previous studies wherein his research examining the Quality of Service, and Consumer Satisfaction of Sumaru Endo Remboken Tourism Objects stated that direct evidence, reliability, responsiveness, assurance, and empathy simultaneously have a partial effect on consumer satisfaction of Sumaru Endo Remboken tourist attraction (Massie 2016; Tsaur et al., 2002; Brady et al., 2002). The results for the effect of reliability on customer satisfaction in Kertalangu Cultural Village shows the value of $t$ count $3,414$ and p-value ( $\mathrm{sig})$ of 0.001 which below alpha $0.05(0.001<0.05)$ which means that the reliability has a positive and significant effect on customer satisfaction in Kertalangu Cultural Village. The beta value in the unstandardized coefficient of the reliability variable indicates of 0.308 , which means that if the reliability variable is increased by one point, the customer satisfaction of Kertalangu Culture Village will increase by $30.8 \%$. The results of this study are supported by previous studies wherein his research examining the Level of Visitor Satisfaction with the Service Quality of the Tomo Peak Temboan Tourism Area which states visitors of the Temboan Peak attraction are satisfied with the quality of services provided by the manager of the Temboan Peak attraction at the level of 75.59\% (Tengkere, 2017).

\section{Conclusion}

Based on the results and discussion in the previous chapter, the following conclusions are obtained:

a) Responsiveness has a positive and significant effect on customer satisfaction in Kertalangu Cultural Village.

b) Assurance has a positive and significant effect on customer satisfaction in Kertalangu Cultural Village.

c) Tangible has a positive effect but not significant in customer satisfaction in Kertalangu Cultural Village.

d) Empathy has a positive and significant effect on customer satisfaction in Kertalangu Cultural Village.

e) Reliability has a positive and significant effect on customer satisfaction in Kertalangu Cultural Village.

\section{Suggestion}

Service quality variables tested in this study are responsiveness, assurance, tangibility, empathy, reliability. The four variables responsiveness, assurance, empathy, reliability, have a positive and significant effect on customer satisfaction in the Kertalangu Culture Village. Unlike the results shown by tangible variables or physical evidence, this variable shows positive but not significant results on customer satisfaction. Physical evidence such as roads, parking lots, jogging track facilities, and other physical facilities directly affect customer satisfaction, but this is not the only measure of customer satisfaction. Judging from these results, customers want adequate physical facilities, but there are have other factors that make them want to keep visiting, and they are satisfied with it. Examples such as enjoying the natural scenery and the addition of entertainment facilities related to culture, customers, or visitors still want to visit the Kertalangu Culture Village, even though the physical facilities still need improvement. It can be a reference for managers to evaluate the existing physical facilities so that visitors can be more satisfied with the existence of physical facilities that are maintained.

Sumartini, A. R., \& Idawati, I. A. A. (2020). Development of culture village through service quality analysis to customer satisfaction. International Research Journal of Management, IT and Social Sciences, 7(3), 98-103. https://doi.org/10.21744/irjmis.v7n3.921 
Conflict of interest statement

The authors declared that they have no competing interests.

Statement of authorship

The authors have a responsibility for the conception and design of the study. The authors have approved the final article.

Acknowledgments

We are grateful to two anonymous reviewers for their valuable comments on the earlier version of this paper. 


\section{References}

Aryani, D., \& Rosinta, F. (2010). Effect of service quality on customer satisfaction in shaping customer loyalty. Journal of Administrative Sciences and Organizations, 17(2).

Brady, M. K., Cronin Jr, J. J., \& Brand, R. R. (2002). Performance-only measurement of service quality: a replication and extension. Journal of business research, 55(1), 17-31. https://doi.org/10.1016/S0148-2963(00)00171-5

Burger, P. C., \& Cann, C. W. (1995). Post-purchase strategy: a key to successful industrial marketing and customer satisfaction. Industrial Marketing Management, 24(2), 91-98. https://doi.org/10.1016/0019-8501(94)00036-V

Clara. (2017). Kualitas Pelayanan Dan Kepuasan Konsumen Objek Wisata Sumaru Endo Remboken. Universitas Sanata Dharma. Yogyakarta.

De Ruyter, K., Bloemer, J., \& Peeters, P. (1997). Merging service quality and service satisfaction. An empirical test of an integrative model. Journal of economic psychology, 18(4), 387-406. https://doi.org/10.1016/S01674870(97)00014-7

Erawan, N. (1993). Pariwisata dalam Kaitannya dengan Kebudayaan dan Kepribadian Bangsa" dalam Kebudayaan dan Kepribadian Bangsa (Tjok Sudharta, dkk. ed.). Denpasar: Upada Sastra.

Fornell, C. (1992). A national customer satisfaction barometer: The Swedish experience. Journal of marketing, 56(1), 6-21. https://doi.org/10.1177\%2F002224299205600103

Kotler, P., \& Keller, K. L. (2009). Manajemen Pemasaran jilid 1 edisi 13. Jakarta: Erlangga.

Ligiya. (2016). Pengaruh Kualitas Pelayanan Terhadap Kepuasan Wisatawan Dalam Berwisata Di Kampung Gajah. STP. Bandung

Malarvizhi, J., \& Devi, T. C. (2018). A Study on Customer Satisfaction towards Patanjali Products in Theni District. International Research Journal of Management, IT and Social Sciences, 5(2), 75-79.

Massie, S. P. M. (2016). Kualitas Pelayanan dan Kepuasan Konsumen Objek Wisata Sumaru Endo Remboken. Jurnal Berkala Ilmiah Efisiensi, 16(1).

Matzler, K., Bailom, F., Hinterhuber, H. H., Renzl, B., \& Pichler, J. (2004). The asymmetric relationship between attribute-level performance and overall customer satisfaction: a reconsideration of the importance-performance analysis. Industrial marketing management, 33(4), 271-277. https://doi.org/10.1016/S0019-8501(03)00055-5

Muljadi, A. J. (2009). Kepariwisataan dan Perjalanan, Jakarta. Pt Rajagra ndo Perkasa.

Oh, H. (1999). Service quality, customer satisfaction, and customer value: A holistic perspective. International Journal of Hospitality Management, 18(1), 67-82. https://doi.org/10.1016/S0278-4319(98)00047-4

Parasuraman, V. A. (2011). A Conceptual Model of Service Quality and Its Implication forr Future Reaserch. Service Quality.

Perkins, W. S. (1993). Measuring customer satisfaction: a comparison of buyer, distributor, and salesforce perceptions of competing products. Industrial Marketing Management, 22(3), 247-254. https://doi.org/10.1016/00198501(93)90012-V

Rianto, R. (2017). Analisis Kualitas Pelayanan Dan Kepuasan Pengunjung Wisata Di Desa Wisata Cibuntu Kabupaten Kuningan (Diagram Kartesius). Jurnal Hospitality dan Pariwisata, 1.

Sugiyono. (2014). Statitiska Untuk Penelitian. Bandung. Alfabeta

Suwantoro, G. (1997). Dasar-dasar Pariwisata, Yogyakarta. Andi Offset.

Tangkere, E. G., \& Lorraine, W. T. (2017). Tingkat Kepuasan Pengunjung terhadap Kualitas Pelayanan Daerah Wisata Puncak Temboan Tomohon. AGRI-SOSIOEKONOMI, 13(1), 35-46.

Tsaur, S. H., Chang, T. Y., \& Yen, C. H. (2002). The evaluation of airline service quality by fuzzy MCDM. Tourism management, 23(2), 107-115. https://doi.org/10.1016/S0261-5177(01)00050-4

Yong, C. Z., Yun, Y. W., \& Loh, L. (2003). The quest for global quality. Pustaka Delapratasa, Jakarta.

Sumartini, A. R., \& Idawati, I. A. A. (2020). Development of culture village through service quality analysis to customer satisfaction. International Research Journal of Management, IT and Social Sciences, 7(3), 98-103. https://doi.org/10.21744/irjmis.v7n3.921 